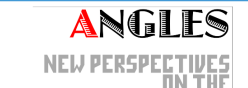

ANELOPHONE WORLD

\section{Angles}

New Perspectives on the Anglophone World

$4 \mid 2017$

Unstable States, Mutable Conditions

\title{
The Aesthetics of Mutability in The Village in the Jungle (1913)
}

\section{Leila Haghshenas}

\section{(2) OpenEdition \\ 1 Journals}

Electronic version

URL: https://journals.openedition.org/angles/1424

DOI: $10.4000 /$ angles. 1424

ISSN: 2274-2042

\section{Publisher}

Société des Anglicistes de l'Enseignement Supérieur

\section{Electronic reference}

Leila Haghshenas, "The Aesthetics of Mutability in The Village in the Jungle (1913)", Angles [Online], 4 I 2017, Online since 01 April 2017, connection on 07 June 2022. URL: http://journals.openedition.org/ angles/1424 ; DOI: https://doi.org/10.4000/angles. 1424

This text was automatically generated on 7 June 2022.

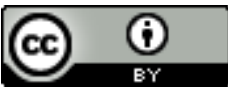

Angles est mise à disposition selon les termes de la Licence Creative Commons Attribution 4.0 International. 


\title{
The Aesthetics of Mutability in The Village in the Jungle (1913)
}

\author{
Leila Haghshenas
}

1 The Village in the Jungle, Leonard Woolf's first novel, was published in 1913, right after the author's return from Ceylon (modern-day Sri Lanka) where he served as a colonial administrator for seven years. Set against the backdrop of colonial rule in Ceylon, the novel depicts the enchanting but menacing life in the jungles of Ceylon, where animals and humans alike are subject to change and mutability. Woolf did not have to research his setting and his characters, contrary to many novelists writing on the East. He could draw on his official diaries, his reports and letters written during his stay in Ceylon. Emerging out of his own colonial experience, The Village in the Jungle reflects Woolf's understanding of life in the jungles of Ceylon, as well as his outlook on the nature of human beings. In Growing, the third volume of his autobiography, Leonard Woolf evokes the implications of his passionate encounter with the jungle people and their way of life:

I fell in love with the country, the people and the way of life. [...] To understand the people and the way they lived in the villages of West Giruwa Pattu and the jungles of Magampattu became a passion with me. [...] I did not idealize or romanticize the people or the country; I just liked them aesthetically and humanly and socially. (Woolf 1975: 159)

2 As Woolf claims, his understanding of the East and its inhabitants is the result of his enduring passion for the village people and their way of life. His passion for the language and culture of the Ceylonese was such that he followed language courses with the help of a Buddhist priest (Woolf 1964: 162). He also managed to observe the jungle people and to grasp the precarious and ever mutable nature of their existence. This mutability is in turn reflected in The Village in the Jungle, where the writer tries "somehow or other vicariously to live their lives" (Woolf 1964: 47-8). Indeed, Woolf's novel is both animated and shaped by multiple and constant mutations, transformations and reversals. Human characters in the novel are described in animal terms, their affinity with nature and the wildlife being the cause of their marginality and invisibility. Likewise, animal characters are attributed human traits and come to 
share the fate and misfortunes of the marginalised characters. What is remarkable about the novel is that the border separating humans and animals, men and women, the visible and the invisible, is so porous and indefinable that every kind of transgression is rendered possible. Mutability thus constitutes the overriding modality of the entire novel, transforming the narrative into a perpetual theatre of metamorphosis.

We shall therefore approach the question of the porosity and instability of the boundaries between the animal and the human, between men and women, or between the various classes or groups within a society, through a study of the general permeability of the orderings and demarcations that are presented in Leonard Woolf's novel. The indefinable boundary between humans and animals, I will argue, is the source of multiple metamorphoses and transformations. We shall then go on to show that the blurring of boundaries between humans and animals in The Village in the Jungle reflects the primal transgression that is inherent to the founding myth of Ceylon, thus foreshadowing the unexpected reversal of power operated by Silindu, the protagonist of the novel. I intend to analyze the reversal of power by drawing on Jacques Rancière's notion of disempowerment and empowerment, introduced in Le maître ignorant: cinq leçons sur l'émancipation intellectuelle (1987). It is indeed through the constant struggle of the humble characters to transcend their disempowered existence that the reversal of power is rendered possible and that an aesthetics of mutability is created. As Woolf suggests, there is a particular instability that is proper to the jungle and to the creatures that live in it. The very first lines of The Village in the Jungle establish the jungle as an all-important and constantly changing setting:

The village was called Beddagama, which means the village in the jungle. It lay in the low country or plains, midway between the sea and the great mountains which seem, far away to the north, to rise like a long wall straight up from the sea of trees. It was in, and of, the jungle, the air and smell of the jungle lay heavy upon it - the smell of hot air, of dust, and of dry and powdered leaves and sticks. Its beginning and its end was in the jungle, which stretched away from it on all sides unbroken, north and south and east and west, to the blue of the hills and to the sea. The jungle surrounded it, overhung it, continually pressed in upon it. It stood at the door of the houses, always ready to press in upon the compounds and open spaces, to break through the mud huts, and to choke up the tracks and paths. (Woolf 1913: 9)

The jungle penetrates the village, so much so that the village is not only "in" but is "of" the jungle. The interwoven senses - the smell of the jungle is that of the village, the colour of the hills is the same as the jungle's - highlight the proximity of the jungle and the village. The biblical description of the village, "its beginning and its end," suggests that the jungle's sacred dominance over the village is an unknown and everencroaching danger. The ominous beginning of the novel thus foreshadows the inevitable ending of the story and the elimination of the village by the jungle. The village is therefore presented as a precarious human and cultural construct, constantly at the mercy of the whims of the jungle, a deity-like figure whose presence fills Silindu, the protagonist, with both fear and passion. As the novel unfolds, the influence of the jungle is clearly demonstrated through the comparison with other manifestations of coercive force: that of the usurious middlemen or that of the colonial overlords and oppressors. In addition to its overwhelming power, the jungle is repeatedly described through metaphors which relate it to the sea. In the passage quoted above, the jungle is compared to a "sea of trees," as if the sea and the jungle were interchangeable settings. 
The jungle-ocean metaphoric link suggests the dynamic and constantly mutating ground on which the village has established itself.

5 The presence of the jungle is felt not only in the village, it is also a quality which inhabits or impregnates the inhabitants. The instability inherent in the jungle is clearly decipherable in the villagers, whose lives are placed under the permanent influence of the jungle. In The Village in the Jungle, the acute resemblance of the village people to the animals of the jungle is striking, a proximity pointed out in the very first pages of the novel:

The spirit of the jungle is in the village, and in the people who live in it. [...] They are very near to the animals which live in the jungle around them. They look at you with the melancholy and patient stupidity of the buffalo in their eyes, or the cunning of the jackal. And there is in them the blind anger of the jungle, the ferocity of the leopard, and the sudden fury of the bear. (14-5)

As the passage clearly demonstrates, local people are described in terms of animality. Similarly, the insults and proverbs used in the novel all relate to animals, with insults such as "jackal", "cattle", "cow", "bull."

7 The protagonist's affinity with the jungle and its animals is singular and uncanny, to the point even of seeming somewhat shocking to the villagers. Besides being a cultivator, Silindu is a hunter, an activity that brings him even closer to the world of animals. His temperament is reminiscent of that of certain animals with which he is in constant contact: "Silindu's passions, his anger and his desires were strange and violent even for the jungle" (16). In addition to this, he is described as "a silent little man, with the pinched-up face of a grey monkey" (15). Silindu is called tikak pissu, which means slightly mad (15). The village has its own reasons for such a judgement, since "Silindu slept with his eyes open like some animals, and very often he would moan, whine and twitch in his sleep like a dog; he slept as lightly as a deer, and would start up from any deep sleep in an instant fully awake" (15). Moreover, he knows the jungle better than anybody else and though he fears it more than all the other villagers, the source of his apprehension is not the presence of the animals lurking within it, it is rather the jungle itself. Silindu, more than any other villager, is aware of the unstable and mutating nature of the jungle. His mastery of the language of animals means that he is capable of communicating with them, an aptitude which renders him all the more alien to his own people. Silindu's conversation with the doe he shot in the jungle demonstrates his capacity to understand the language of animals. Having unknowingly shot a doe that has just given birth to a fawn, Silindu promises to take the "child" to Hinnihami to breastfeed: "mother, the daughter at home this night bore a child. I will take this one too to her, as she will give it the breast" (84). The word "child," used to refer both to the human child and to the fawn, points to the proximity between animals and humans in the novel. Silindu's behaviour towards the doe is indeed "humane", though in a manner which goes beyond the clear demarcations of an Enlightenment law of "humanity" and the "humane", insofar as it makes one aware of the erosion in the novel of any clear-cut boundary between the human and the animal. Indeed, Woolf seems to propose a new definition of humanity involving the apprehension of the trans-species dependence of the human on a more encompassing, shared animality. As Herz maintains, Woolf understood human nature in terms of its conditioning animality (Herz 82). 
8 Likewise, the estrangement of Silindu's twin daughters from the rest of the village society is brought about by their extreme proximity with the jungle and the jungle animals. The girls spend most of their time hunting with their father in the jungle. As a result, they grow up to be different from other village children. They are healthy and beautiful, soon becoming the objects of the jealousy of women in the village, who call them veddas ${ }^{1}$ (wild girls). They are usually identified as yakkas or devils and grow up to be outcasts, just like their father. Furthermore, their skin is compared to "the coat of fawn when the sun shines on it" (23), a description pointing to their affinity with the jungle. In an examination of Woolf's divided attitude, Goonetilleke claims that Woolf was "unconsciously schizoid" (Goonetilleke 170), since despite the sympathy for the local people, the novel's description of them in terms of animality repeatedly lapses into the "colonialist topos of displaced savagery" which was widespread among colonial writers (Boehmer 135). I would rather suggest that Leonard Woolf's sympathy towards the Ceylonese culture and language, as reflected in this novel, is indicative of his first-hand knowledge of the East and of his indefatigable efforts to express the reality of life in Ceylon.

9 Leonard Woolf was fascinated by animals. In Downhill All the Way, he expresses his ambivalent attitude towards zoos (Woolf 1975: 42). He experienced both delight and sadness while watching the animals through the iron cages. He believed that one could learn much about the character of the society that had built the zoo by seeing how it treated its animals. In Mitz: The Marmoset of Bloomsbury, Nunez highlights Woolf's attachment to a marmoset that had been given to him by Victor Rothschild. As Stearns notes, Woolf's passion for animals and his metaphoric use of zoos was profoundly rooted in his career as a writer and thinker (Stearns 5). Indeed, one of Woolf's many responsibilities in Ceylon consisted in visiting different areas within his district. In Leonard Woolf: An Imperial Journey in the Shadow of Leonard Woolf (2006), Leonard's responsibilities as an AGA, or Assistant Government Agent, are described as follows: "to collect revenue, dispense justice and to travel regularly 'on circuit' throughout his district, in order to become familiar with every village and its headman, who acted unpaid, as intermediary with the colonial administration" (Ondaatje 106). It was Woolf's authentic knowledge of Ceylon and its people that was the source of the animalistic portrait of the native characters to be found in the novel. What is remarkable in Woolf's fiction is the interest he manifests for the individual predicament and his renewed outlook on life and civilisation. He intimates, within the aspect or the social manifestation of every individual, the enduring presence of what he calls the "human animal" (Woolf 1960: 96), thus recognizing in modern man the persistence of those same primitive desires that dominate the life of the primitive village societies in Ceylon. Woolf's view of humanity is therefore in harmony with the Derridean conception of "human nature", a conception that has been transformed and deconstructed by way of the questioning of the established, defining demarcations and the consequent exposure of the porosity of the notions of "animality" and "humanity". As Derrida argues, each time that a man or philosopher utters the words "animal", he is not only confirming his own animality but is also engaging in a "veritable war of species" (Derrida 400). He thus draws our attention to the animal that exists in each and every one of us. He further argues that despite man's effort to widen the breach between the animal and the human, his internal and neglected animal is bound to surface from time to time, reminding him of the true nature of his humanity. 
10 During his time in Ceylon, Woolf spent much time reflecting on the mass of people passing through his office, conscious of the uniqueness and fragility of each of them. His knowledge of Ceylonese society, of people's customs and of the complicated system of caste and class, was achieved as a result of his acute powers of observation. The Village in the Jungle reflects the conflictual relations between social classes, a tension which constitutes another source of instability in the novel. Poole argues that Woolf had managed to become better acquainted with Ceylon's social and racial system, to the point where he was capable of speculating not only on the way his characters spoke and behaved but he could also speculate on the unconscious assumptions they made (Poole 74). By placing at the centre of the narrative in The Village in the Jungle the struggle of two lovers to marry across the caste system, Woolf seems to be deliberately referring to the highly unstable class-conscious society of Ceylon. Babun Appu, a young man of twenty-one joins the head-man's household in the village and falls in love with Punchi Menika, Silindu's daughter. Silindu, however, belongs to a lower caste and so are his daughters. Any alliance between the two classes is deemed disastrous both by the headman who contemplates a more profitable marriage for Babun as well as by Silindu who fears the separation from his daughter. The marriage of Babun and Punchi Menika destabilizes the existing system of caste and exposes the fatal mutations that are inevitably corroding its performative claim to enact a rule of strict permanence or immutability.

11 Blurred gender barriers constitute another instance of instability in the novel. The handsome, long-haired Babun displays signs of androgyny: "His expression was curiously virile and simple, but his brown eyes, which were large and oval shaped, swept it at moments with something soft, languorous and feminine" (45). Punchi Menika and Hinnihami are also presented as beautiful and androgynous twin sisters, whose excursions into the wild jungle set them apart, rendering them suspect in the eyes of villagers given that the jungle is considered as a masculine sphere. Their artfully and culturally-fashioned feminine beauty, coupled with "their muscles firm as a man's", transform them into androgynous figures (26). Though both sisters manifest signs of androgyny, the blurring of gender boundaries is more complex in the case of Hinnihami, who displays signs of divine androgyny. The village calls her a yakkini, a she-devil capable of self-reproduction, an accusation based on her attachment to a fawn found in the jungle. A speech by the vedelala, the village medicine man, is telling: "Do not she-devils give birth to devils? Do village women suckle deer? Surely it is a devil, born of a devil. Look at the evil that fell upon the village when it came. The crops withered, and the old and the young died. It has brought us want and disease and death" (86).

Other examples of divine androgyny can help us to better grasp the nature of Hinnihami's gender ambiguity. In the ancient Greek theogonies, the holy beings, whether female or neuter, reproduce alone. This kind of parthenogenesis implies androgyny. In Cyprus, a bearded Aphroditie is venerated; in Italy, a bald Venus is worshipped (Eliade 156-7). In similar fashion, Hinnihami is said to show signs of sacred androgyny. On the same night that Hinnihami gives birth to a girl, Silindu brings her a fawn to breast-feed, a "son from the jungle". She takes this as a gift from the gods and comes to love the fawn even more than her own daughter. Her attachment to the fawn that she names Punchi Appu is so great that it/he becomes her permanent company. In fact, she is convinced that as long as she has the blessing of the gods no evil will be able 
to hurt her. Hinnihami's attachment to Punchi Appu epitomizes the instability of strict dividing lines between animals and humans, as well as the blurred gender boundaries upon which the novel is based.

13 As I have demonstrated, no secure dividing line can be drawn between humans and animals in The Village in the Jungle. This is a source of confusion throughout the novel, giving birth to a series of symbolic transformations which are enacted by Silindu and one of his daughters, Hinnihami. Silindu metamorphoses himself into a wounded and angry animal, and Hinnihami turns into a she-devil ready to kill her enemies. Haunted for years by the head man of the village and mistreated by the colonial justice system, Silindu turns to the world of animals and manages to transcend his invisibility through a symbolic act of transgression reminiscent of the primal transgression recounted in the origin story of Ceylon. The following summary will help to elucidate the role of the stranger king and his initial transgression in the construction of the narrative of The Village in the Jungle.

14 For centuries, the Sinhalese have believed they come from Vijaya, a prince who arrived to Lanka from northern India. Legend has it that Vijaya descended from a lion through his father Sinhabāhu ("arm of the lion"). Vijaya was a miscreant and became a threat to the people. Considered as an outsider and dangerous, he was cast out to sea with his 700 followers. He eventually landed on the shores of Lanka, which was then only inhabited by 'demons' (yakkhas). As he arrived, the Buddha lay dying; he prophesied that Vijaya would establish and protect his teachings in Lanka. On the island, Vijaya encountered Kuven, a demon queen who bewitched and trapped his men. With the help of the god Upulvan, Vijaya managed to deceive Kuven. Thanks to Vijaya, cities were founded and the followers demanded that Vijaya be consecrated as king. They became known as the Sinhala, taking their name from Vijaya's leonine origins (Strathern 52-3).

15 It is thus apparent that bestiality and transgression are key themes in the founding myth of Sri Lanka. The hero of royal lineage who came from afar was an outsider and of leonine origin. He managed to release the island from the evil demons and reestablished peace and order. As Sthrathern remarks, "Only someone loaded with associations of the negative, natural and marginal will be able to effect order" in the society (Strathern 53). In the same manner, Silindu, an outsider on the margins of society, manages to momentarily restore order in the little village of Beddagama through a return to his animal origins. Silindu voices his discontent through a double murder, an act involving a complete transgression of the rules of colonial society. His moment of transition, from a calm and ignorant subject to a cunning and dangerous animal, constitutes the climax of the novel and is represented through a long interior monologue:

'They call me a hunter, a vedda? A fine hunter! To be hunted for years now and not to know it! It is the headman who is the vedda, a very clever hunter. I have been lying here like a fat old stag in a thicket while he was crawling, crawling nearer and nearer, round and round, looking for the shot.

Where was the watching doe to cry the alarm? Always he shot me down as I lay quiet. But the old hunter should be very careful. In the end misfortune comes. Perhaps this time I am a buffalo, wounded. The wise hunter does not follow up the wounded buffalo, where the jungle is thick. Ha! ha!

The wounded buffalo can be as clever as the clever hunter. He hears the man crawling and crawling through the jungle. He stands there out of the track in the shadows, the great black head down, the blood bubbling through the wound, listening to the twigs snap and the dry leaves rustle; and the man comes nearer and 
nearer. Fool! you cannot see him there, but he can see you now; he will let you pass him, and then out he will dash upon you, and his great horns will crash into your side, and he will fling you backwards through the air as if you were paddy straw. The old buffalo knows, the old buffalo knows; the young men laugh at him, "buffaloes' eyes," they say, "blind eyes, foolish eyes, a foolish face like a buffalo," but he is clever, amma! he is clever-when wounded-when he hears the hunter after him - cleverer than the cleverest hunter. And when it has gone on for years! all his life! What will he do then? Will he lie quiet then? Oh! he will lie quiet, yes, and let them take all from him, daughter and home and food. He will shake his head and sigh the great sigh, and lie quiet in the mud of the wallow, very sad. And then at last they come after his life. Shall they take that too? Then at last he knows and is angry-very angry-and he stands waiting for them. The fools! They come on, crawling still; they do not know that he is ready for them now. The fools! the fools!' wounded animal of the jungle, a "wounded buffalo" or "a fat old stag". What drives this naïve and subjugated man into action is a renewal of his animal instinct. His affinity with the wild world of animals, regarded as the main cause of his estrangement from the civilized society, thus becomes the main source of his newly-gained power. The hunting metaphor, along with the frequent use of the same semantic field or the field pertaining to animals, such as "hunt", "crawl", "wounded buffalo", "blood", "old stag", point to the animalistic nature of Silindu's rage and its empowering nature. Animality here plays a double role. In one respect, it can be understood as the symptom of the precarious condition and of the invisibility of the principal characters. In another, it can be regarded as an uncanny and dreadful mode of empowerment and selfexpression. The process of empowerment in the novel can thus be understood in the light of Rancière's notion of disempowerment and empowerment, elaborated in Le maitre ignorant. Woolf regards animality as being both disabling and enabling, disempowering and empowering. Silindu's monologue highlights the ambiguous and potentially reversible nature of animality as both a force and a weakness. In Le fil perdu, Rancière explains the capacity of ignored people to break away from the identities imposed on them by society and to take their destiny into their own hands.

Mais la littérature nouvelle opère aussi une scission au sein même de cette égalité sensible qui lie les transformations de la forme romanesque aux rébellions silencieuses ou bruyantes des hommes et femmes du peuple en quête d'une autre vie [...] des fils d'ouvrier ou des filles de paysans, identifiés par l'occupation d'une place dans la totalité sociale et destinés à la forme de vie correspondant à cette position, rompent avec cette assignation identitaire. Ils rompent avec l'univers de la vie invisible et répétitive pour mettre en œuvre des capacités et vivre des formes de vie qui ne correspondent pas à leur identité. (Rancière 2014:32)

Rancière's views about the capacity of what Spivak called "the subaltern" (1988) subject to voice its discontents are thus in fundamental agreement with those of Woolf. The animal-like man, made aware of his subversive power, breaks away from his assigned identity as a 'poor', 'ignorant', 'little' colonial subject, adopting a new mode of selfidentification, more in harmony with his needs and temperament (133). Silindu's rejection of the institutional forms of colonial justice should therefore be considered as an act of transgression, one which allows him to recover his original identity. Therefore, in The Village in the Jungle, the subaltern can speak, through a symbolic return to its roots. 
The metamorphosis of Hinnihami, Silindu's daughter, is another example of the reversal of power that is provoked through the recourse to the world of jungle. Failing to convince Silindu to offer him the hand of Hinnihami, the Punchirala, or village magician, casts a deadly spell upon him. In order to save her father from certain death, Hinnihami is obliged to succumb to the magician's demand. Once his father has recovered from his illness, Hinnihami decides to leave the Punchirala to join her father. Her moment of transformation into a yakkini, a she-devil, is described in the following passage:

'Do you wish me to stay in the house? [...] Do not I too come from the jungle? I shall be like a yakkini to you in the house, you dog. You can tell them, they say, by the eyes which do not blink. Rightly the village women call me yakinni. I will stay with you. Look at my arms. Are they not as strong as a man's arms?'

Punchirala instinctively stepped back, and Hinnihami laughed. 'Ohé! are you frightened, Punchirala? The binder of yakkas is frightened of yakkini. You can tell her, they say, because her eyes are red and because she neither fears nor loves. It's better for you that I might go back to the trees from which I come mighty vederala, otherwise, I would strangle you, and eat you in the house [...]'. (81)

Once again, the victim's proximity with the jungle, which initially had been the cause of her estrangement from the rest of the society, here serves as a means of empowerment, enabling her to set herself free from Punchirala. As Le Blanc suggests, a tramp gets his strength from his inferior position in society and his incapacity to rise in the social hierarchy (Le Blanc 10). ${ }^{3}$ Likewise, Hinnihami's association with yakkinis and with the animals of the jungle enables her to operate a symbolic metamorphosis. The animal rage of Hinnihami is such that the fear-stricken Punchirala has no choice but to set her free.

The Village in the Jungle interrogates the unstable and mutable boundaries shaping the life of Ceylonese villagers, in the context of the colonial order of power whose deployment involves an imperiously strict demarcation of conditions and states. The novel thus exposes the intrinsic and structural limits to the vulnerability and disempowerment of these subjects. The novel explores the mutable and continuously changing boundaries of gender, social class and animality in the village of Beddagama and puts forward an authentic and shifting vision of the East. Inspired by the local culture and the rich mythical heritage of Ceylon, Woolf creates an unstable fictional universe, a microcosm where different aspects of the villagers' lives are exposed and addressed. The deliberate ambiguity present in the novel seems to point to the instability of the established power relations, thus pointing to the possibility of transgressing social differences and barriers. In the novel, the symbolic transformation of Silindu and his daughter reflects the mutable state of human beings and suggests that the absolute of sovereignty is in fact reversible. This aptitude for transformation in Leonard Woolf's novel is accompanied by attempts on the part of the disempowered and invisible colonial subject to reverse the balance of power and to regain sovereignty. In Le maitre ignorant, Rancière considers the "humble," as a condition or modality that is both disabling and enabling, disempowering and empowering, thus placing the emphasis on the unstable nature of power relations. Assimilated to animals and mistreated by the colonial justice system, a marginal character such as Silindu can thus reaffirm his authority by following the law of the jungle and by punishing those responsible for his misery. In this way, he manages to modify and redefine the limits of his invisibility and marginality. Silindu's transition from the status of invisible and insignificant colonial subject to that of a sovereign and independent human being is 
therefore brought about by a return to his leonine origins, a metamorphosis reflecting the mutable state of human beings and of the power relations in which they are caught up. The novel reflects Woolf's vision of the East and its humanity, an Orient in constant mutation.

\section{BIBLIOGRAPHY}

Boehmer, Elleke. "Metropolitans and Mimics". Colonial and Postcolonial Literature: Migrant Metaphors. 2nd ed. Oxford: Oxford UP, 2005. 132-71.

Derrida, Jacques. “The Animal That Therefore I Am (More to Follow)." Trans. David Wills. Critical Inquiry 28. 2 (Winter 2002): 369-418. https://www.jstor.org/stable/1344276

Eliade, Mircea. Méphistophélès et l'androgyne. Idées. Paris: Gallimard, 1981. 156-157.

Goonetilleke, D.C.R.A. "Leonard Woolf's Divided Mind: The Case of The Village in the Jungle." Ariel: A Review of International English Literature 38.2-3 (2007): 159-170. https://

journalhosting.ucalgary.ca/index.php/ariel/article/view/31230

Herz, J. S. “To Glide Silently Out of One's Own Text: Leonard Woolf and 'The Village in the Jungle”.' Ariel : A Review of International English Literature. 32.4 (2001): 69-87. https:// journalhosting.ucalgary.ca/index.php/ariel/article/view/34691

Le Blanc, Guillaume. L'insurrection des vies minuscules. Montrouge: Bayard, 2014.

Ondaatje, Christopher. Woolf in Ceylon: An Imperial Journey in the Shadow of Leonard Woolf. 1904-1911. Geneva: The Long Riders' Guild Press, 2006.

Poole, Roger. The Unknown Virginia Woolf. Cambridge: Cambridge UP, 1995.

Rancière, Jacques. Le maître ignorant: cinq leçons sur l'émancipation intellectuelle. Paris: Fayard, 1987.

Rancière, Jacques. Le fil perdu: essais sur la fiction moderne. Paris: La Fabrique, 2014.

Spivak, Gayatri Chakravorty. “Can the Subaltern Speak?". In Marxism and the Interpretation of Culture. Ed. C. Nelson and L. Grossberg. Chicago: U. of Illinois P., 1988. 271-313.

Stearns, Stephen J. "Introduction". In In Savage Times: Leonard Woolf on Peace and War. New York: Garland Publishing, 1973. 5-13.

Strathern, Alan. "Vijaya and Romulus: Interpreting the Origin Myths of Sri Lanka and Rome". Journal of the Royal Asiatic Society 24.1 (2014): 51-73. DOI: 10.1017/S1356186313000527

Woolf, Leonard. The Village in the Jungle: A Novel. London: Eland, [1913] 2005.

Woolf, Leonard. Sowing: An Autobiography of the Years 1880-1904. London: The Hogarth Press, 1960.

Woolf, Leonard. Growing: An Autobiography of the Years 1904 to 1911. New York: Harcourt Brace Jovanovich, 1975.

Woolf, Leonard. Beginning Again: An Autobiography of the Years 1911 to 1918. London: The Hogarth Press, 1964. 


\section{NOTES}

1. Veddas are aborigines of Ceylon and are or were hunters.

2. In Sowing: An Autobiography of the Years 1880-1904 (1960), Leonard Woolf describes human beings in terms of animality by using the expression "human animal".

3. "Le vagabond est le désinscrit qui tire sa force de sa faiblesse sociale, de son impossibilité à être dans le rang" (Le Blanc 10).

\section{ABSTRACTS}

This paper focuses on the representation of change and mutability in Leonard Woolf's The Village in the Jungle (1913) and the creation of an aesthetics of mutability. It suggests that the novel's unstable state emerges out of Woolf's understanding of the East and its people and from his perspective on the question of the nature of humanity. Woolf seems to refuse the Conradian perception of the East as immutable and to propose instead a new and realistic vision of the orient and its people, that of a constantly moving and evolving East. The inherent instability of the jungle, it is argued here, extends to the village and its inhabitants and expresses itself through the blurring of boundaries between humans and animals, social classes and even genders. Multiple transformations and reversals in The Village in the Jungle point to the novel's affinity for unstable states and mutable conditions.

Cet article a pour objet la représentation du changement et de la mutabilité dans The Village in the Jungle (1913) de Leonard Woolf et l'invention dans le roman d'une esthétique de la mutabilité. Il émet l'hypothèse que l'état instable du roman découle d'une compréhension de l'orient et de sa population et d'une perspective concernant la nature de l'humanité qui sont propres à Woolf. Woolf semble récuser la perception conradienne d'un orient immuable, proposant à la place une vision nouvelle et réaliste de la région et de sa population : un orient en mouvement et en évolution constants. L'argument avancé est donc que l'instabilité inhérente à la jungle s'étendrait au village et à ses habitants, s'exprimant à travers le brouillage des frontières entre humains et animaux, entre classes sociales et même entre genres. Les nombreuses transformations et inversions dans The Village in the Jungle témoigneraient d'une affinité dans ce roman pour les états instables et les conditions muables.

\section{INDEX}

Mots-clés: Woolf Leonard, Village in the Jungle (The), Ceylan, mythe, instabilité, mutabilité, métamorphose

Keywords: Woolf Leonard, Village in the Jungle (The), Ceylon, myth, unstable, mutability, metamorphosis 


\section{AUTHOR}

\section{LEILA HAGHSHENAS}

Leila Haghshenas is a doctoral student in English Literature at Paul-Valéry University, Montpellier. She is writing a PhD on the ethics of alterity in Leonard Woolf's literary work. She has participated in national and international conferences. 'The Aesthetics of Humility in The Village in the Jungle' is forthcoming in Horizons anglophones, Present Perfect. Contact:

leilahaghshenas [at] yahoo.com 